\title{
Pengaruh Entrepreneurial Marketing dan Kebijakan Pemerintah terhadap Daya Saing Industri Alas Kaki di Bogor
}

\author{
Stevia Septiani \\ Departemen Manajemen, Fakultas Ekonomi dan Manajemen \\ Institut Pertanian Bogor \\ Kampus Dramaga Bogor 16680 \\ Ma'mun Sarma \\ Departemen Manajemen, Fakultas Ekonomi dan Manajemen \\ Institut Pertanian Bogor \\ Kampus Dramaga Bogor 16680 \\ mamun_sarma@yahoo.com \\ Wilson H. Limbong \\ Departemen Manajemen, Fakultas Ekonomi dan Manajemen \\ Institut Pertanian Bogor \\ Kampus Dramaga Bogor 16680
}

\begin{abstract}
Entrepreneurial marketing is the suitable approach in terms of resource constraints and problems that exist in small and medium enterprises (SMEs). Footwear industry is a sector of Small and Medium Enterprises (SMEs) that is supported by the government of Bogor. Problems of development of footwear industry are divided into two main factors: the competence of SMEs and local government policy. Based on these problems, this study aims to (1) Identify the characteristics of entrepreneurs, business characteristics and linkages both of them, (2) Identify and analyze the ability of entrepreneurial marketing, implementation of government policies and the ability of the competitiveness of small industrial footwear in Bogor, and (3) Identify and analyze the influence of entrepreneurial marketing and government policies on the competitiveness of the footwear industry in Bogor. Sample selection is done by purposive cluster sampling method. The samples in this study were 100 small business owners. This study employs three data analysis: descriptive analysis, index transformation analysis, and analysis of Structural Equation Modeling (SEM) with Partial Least Square (PLS). Characteristics of footwear SME owners in Bogor is included the low-educated group. However, they have excellent expertise in the producing of footwear. Characteristics of footwear enterprises in Bogor, is categorized as the long standing and major businesses. Based on the analysis of SEM with PLS approach, it is known that the entrepreneurial marketing variables have a positive impact on the competitiveness of small industrial footwear in Bogor, while the government policies variables have an indirect effect on competitiveness through entrepreneurial marketing variables.

Keyword: entrepreneurial marketing, competitiveness, SMEs, footwear industry, PLS
\end{abstract}

\begin{abstract}
ABSTRAK
Entrepreneurial marketing adalah pendekatan pemasaran yang lebih sesuai ditinjau dari keterbatasan sumber daya dan permasalahan yang ada pada industri kecil dan menengah (IKM). Industri alas kaki adalah sektor IKM yang didukung oleh pemerintah Bogor. Meski telah mendapatkan dukungan dari pemerintah setempat, industri ini tidak luput dari berbagai kendala. Masalah pengembangan
\end{abstract}


industri alas kaki dibagi menjadi 2 faktor utama, yaitu: kompetensi pelaku IKM dan kebijakan pemerintah daerah. Berdasarkan permasalahan tersebut, penelitian ini bertujuan untuk: (1) Mengidentifikasi karakteristik pelaku usaha, karakteristik usaha dan keterkaitan keduanya pada industri kecil (IK) alas kaki di wilayah Bogor, (2) Mengidentifikasi dan menganalisis kemampuan entrepreneurial marketing, implementasi kebijakan pemerintah dan kemampuan daya saing pelaku usaha IK alas kaki di wilayah Bogor dan (3) Mengidentifikasi dan menganalisis pengaruh entrepreneurial marketing dan kebijakan pemerintah terhadap daya saing industri alas kaki di wilayah Bogor. Pemilihan contoh dilakukan dengan metode purposive cluster sampling. Sampel dalam penelitian ini adalah 100 pelaku usaha kecil alas kaki di Bogor. Penelitian ini menggunakan tiga analisis data, yaitu, analisis deskriptif, analisis transformasi indeks, dan analisis Structural Equation Modeling (SEM) dengan pendekatan Partial Least Square (PLS). Berdasarkan hasil pengolahan data diketahui bahwa karakteristik pelaku industri kecil alas kaki di Bogor termasuk pada kelompok berpendidikan rendah, namun memiliki keahlian sangat baik dalam memproduksi alas kaki. Karakteristik usaha alas kaki di Bogor termasuk pada usaha yang telah lama berdiri dengan kategori IK dan merupakan usaha atau bisnis utama keluarga. Selanjutnya, berdasarkan analisis SEM dengan pendekatan PLS, diketahui bahwa peubah laten entrepreneurial marketing berpengaruh secara positif dan langsung terhadap daya saing industri kecil alas kaki di Bogor. Sedangkan peubah laten kebijakan pemerintah ternyata memiliki dampak langsung dan positif terhadap entrepreneurial marketing, sehingga dapat diartikan bahwa terdapat pengaruh tidak langsung antara kebijakan pemerintah terhadap daya saing melalui entrepreneurial marketing.

Keyword: entrepreneurial marketing, daya saing, IKM, industri alas kaki, PLS

\section{Pendahuluan}

Kemunculan konsep entrepreneurial marketing merupakan respon dari beberapa hasil penelitian yang menunjukkan adanya ketidaksesuaian antara teori pemasaran tradisional dan praktek pemasaran pada pelaku usaha kecil dan menengah, atau UKM (Ionita 2012). Berdasarkan kondisi tersebut diketahui bahwa konsep pemasaran yang ada (pemasaran tradisional) yang awalnya dikembangkan untuk perusahaan besar, tidak dapat langsung ditransfer ke dunia usaha kecil tanpa adaptasi. Hal itu atas dasar penerapan konsep pemasaran oleh para pelaku IKM yang dipraktekkan dengan cara yang berbeda dari buku teks pemasaran tradisional (Kraus et al. 2007). Hasil penelitian tersebut memberi gambaran bahwa dibutuhkan keberadaan konsep pemasaran yang lebih sesuai dengan karakteristik khas yang dimiliki IKM.

Entrepreneurial marketing merupakan konsep yang awalnya muncul pada pelaku usaha skala kecil atau pelaku usaha yang baru memulai bisnisnya. Pendekatan pemasaran kewirausahaan merupakan pendekatan kotingensi yang lebih sesuai, ditinjau dari keterbatasan sumber daya dan permasalahan yang ada pada UKM (Stokes 2000). Dalam penerapan entrepreneurial marketing, pemilik UKM cenderung berorientasi pada inovasi dan melakukan strategi bottom-up (menyesuaikan produk dengan permintaan konsumen). Hal ini sangat relevan dengan karakteristik industri alas kaki yang notabene peka terhadap perubahan varian model yang begitu cepat, sehingga membutuhkan strategi inovasi yang tepat dari para pelaku usaha.

Industri alas kaki merupakan salah satu sektor Industri Kecil dan Menengah (IKM) non migas yang didukung oleh pemerintah. Dukungan dari pemerintah tersebut diperkuat dengan adanya regulasi dalam Rencana Pembangunan Jangka Menengah Nasional (RPJMN) yang diatur oleh Peraturan Presiden No. 7/2005 yaitu mengenai pengembangan industri alas kaki yang dinilai berpotensi dalam pembangunan nasional. Dalam lingkungan bisnis yang turbulen, pelaku IK alas kaki dituntut untuk melakukan berbagai langkah strategis agar mampu berdaya saing. Peningkatan daya 
saing salah satunya dapat dicapai melalui strategi inovasi yang merupakan wujud dari kreatifitas yang dihasilkan oleh pengelola usaha (Rofiaty 2010), yang juga merupakan cerminan dari penerapan konsep entrepreneurial marketing.

Bogor merupakan salah satu sentra IKM alas kaki di Jawa Barat setelah Cibaduyut, Bandung. Baik wilayah Kota maupun Kabupaten Bogor, keduanya begitu potensial untuk pengembangan industri alas kaki. Potensi IKM alas kaki selengkapnya dapat dilihat pada Tabel 1, di mana data pada tabel tersebut merupakan rekap data terkini yang dimiliki pihak Dinas terkait di masing-masing wilayah.

Tabel 1. Potensi IKM alas kaki di Bogor

\begin{tabular}{lcc}
\hline \multicolumn{1}{c}{ Indikator } & $\begin{array}{c}\text { Kabupaten Bogor } \\
\text { (Tahun 2011) }\end{array}$ & $\begin{array}{c}\text { Kota Bogor } \\
\text { (Tahun 2003) }\end{array}$ \\
\hline Kapasitas produksi per tahun (kodi) & 1.863 .360 & 3.568 .272 \\
Jumlah unit usaha (orang) & 1.941 & 240 \\
Jumlah tenaga kerja (orang) & 18.108 & 3.200 \\
\hline
\end{tabular}

Sumber: Data Diskoperindag Kabupaten Bogor dan Disperindag Kota Bogor, diolah (2012)

Meski Bogor merupakan salah satu sentra IK alas kaki yang potensial, namun perkembangan industri ini masih kurang nyata. Data Unit Pelayanan Teknis (UPT) menunjukkan hanya sekitar 5\% UKM alas kaki yang berkembang menjadi usaha besar. Jika dikelompokkan, permasalahan dalam pengembangan IK alas kaki di wilayah Bogor terbagi menjadi dua faktor utama: (1) faktor internal, yaitu kompetensi pelaku usaha; dan (2) faktor eksternal, yaitu kebijakan pemerintah daerah. Hal ini sesuai dengan penelitian Utami (2007) yang menyatakan bahwa model pemberdayaan yang efektif bagi para pengrajin adalah dengan meningkatkan mutu perilaku wirausaha dan kemandirian usaha, yang didukung oleh unsur penunjang dari pemerintah daerah dan organisasi non pemerintah. Berdasarkan informasi tersebut, maka perumusan masalah penelitian dikemukakan dalam pertanyaan berikut:

1. Bagaimana karakteristik pelaku usaha, karakteristik usaha dan keterkaitan keduanya pada IK alas kaki di wilayah Bogor?

2. Bagaimana kemampuan entrepreneurial marketing, implementasi kebijakan pemerintah dan kemampuan daya saing pelaku usaha IK alas kaki di wilayah Bogor?

3. Bagaimana pengaruh entrepreneurial marketing dan kebijakan pemerintah terhadap daya saing industri alas kaki di wilayah Bogor?

Sejalan dengan permasalahan yang dirumuskan, maka tujuan penelitian ini adalah:

1. Mengidentifikasi karakteristik pelaku usaha, karakteristik usaha dan keterkaitan keduanya pada IK alas kaki di wilayah Bogor.

2. Mengidentifikasi dan menganalisis kemampuan entrepreneurial marketing, implementasi kebijakan pemerintah dan kemampuan daya saing pelaku usaha IK alas kaki di wilayah Bogor.

3. Mengidentifikasi dan menganalisis pengaruh entrepreneurial marketing dan kebijakan pemerintah terhadap daya saing industri alas kaki di wilayah Bogor.

Pada dasarnya penelitian ini merupakan penelitian dengan konsep teori yang cukup baru. Landasan teori yang digunakan dalam penelitian ini mengacu pada penelitian Stokes (2000) dan Hills (2008) tentang entrepreneurial marketing. Prinsip-prinsip 
pemasaran yang digunakan dalam teori entrepreneurial marketing terdiri dari empat jenis, yang mana tiga jenis seperti concept, strategy, methods, mengacu pada penelitian Crosier (2006) dan prinsip keempat yaitu market intelligence, mengacu pada pendapat Kohli dan Jaworski (2005).

Dikarenakan konsepnya yang relatif baru, maka belum banyak penelitian yang membahas tentang konsep ini. Jika beberapa penelitian terdahulu menelusuri potensi industri kecil alas kaki di wilayah Bogor secara partial, penelitian ini justru mengkaji potensi industri kecil alas kaki di wilayah Bogor secara menyeluruh, baik pada wilayah Kota maupun Kabupaten Bogor. Selanjutnya, perbedaan peubah yang diteliti dan alat analisis yang digunakan merujuk pada penelitian Hadiyati (2009). Bila pada penelitian Hadiyati (2009) mengkaji pengaruh entrepreneurial marketing terhadap kinerja penjualan dengan menggunakan analisis regresi, maka pada penelitian ini memiliki lingkup yang lebih kompleks yang mengkaji pengaruh entrepreneurial marketing dan kebijakan pemerintah terhadap daya saing dengan menggunakan analisis Structural Equation Modeling (SEM) melalui pendekatan Partial Least Squares (PLS). Model pengembangan yang akan diuji dapat dilihat pada Gambar 1.

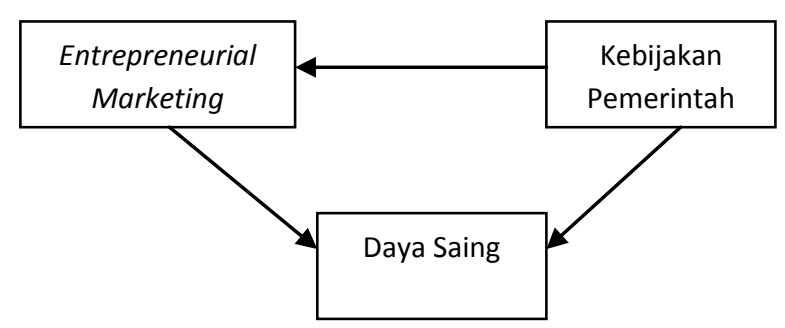

Gambar 1. Kerangka konseptual IKM alas kaki Bogor

\section{Metode Penelitian}

Wilayah Bogor merupakan salah satu sentra industri kecil alas kaki yang potensial untuk dikembangkan. Namun, ironisnya mayoritas pelaku IK alas kaki di wilayah Bogor masih berada pada kondisi yang tidak ideal, dimana IK alas kaki tidak mengalami perkembangan yang nyata dan tidak jauh berbeda kondisinya ketika awal didirikan.

Melihat begitu pentingnya entrepreneurial marketing dan kebijakan pemerintah dalam mengoptimalkan daya saing industri alas kaki, maka dilakukan analisis pengaruh antar peubah-peubah tersebut melalui analisis SEM dengan pendekatan PLS, dimana pencapaian pada masing-masing peubah tersebut telah diketahui sebelumnya melalui analisis transformasi indek.

Di sisi lain, karakteristik pelaku usaha juga memainkan peranan penting dalam membentuk kemampuan entrepreneurial marketing dan karakteristik usaha yang ada. Sehingga, pada penelitian ini dilakukan juga analisis tabulasi silang (cross tabulation) terhadap peubah-peubah tersebut untuk melihat potensi keberlanjutan IK alas kaki di Bogor secara umum. Kerangka pemikiran penelitian lebih lengkapnya dapat dilihat pada Gambar 2.

Berdasarkan tujuan penelitian dan beberapa tinjauan penelitian terdahulu, maka hipotesis penelitian yang dapat dirumuskan sebagai berikut: 
H1 : Entrepreneurial marketing berpengaruh positif terhadap daya saing industri alas kaki di wilayah Bogor.

H2 : Kebijakan pemerintah berpengaruh positif terhadap daya saing industri alas kaki di wilayah Bogor.

H3 : Kebijakan pemerintah berpengaruh positif terhadap entrepreneurial marketing pelaku IK alas kaki di wilayah Bogor.

Penelitian berlokasi di wilayah pengembangan industri alas kaki di Bogor. Untuk wilayah Kabupaten Bogor, sentra produksi alas kaki yang diteliti adalah Kecamatan Ciomas, sedangkan di Kota Bogor sentra alas kaki yang diteliti adalah Kecamatan Bogor Selatan. Penelitian dilakukan selama tiga bulan, yaitu bulan Juni sampai dengan Agustus 2012.

Data yang digunakan pada penelitian ini adalah data primer dan data sekunder. Data primer diperoleh dari informasi yang diberikan oleh pihak UPT Pengembangan Industri Alas Kaki Kabupaten Bogor dan pelaku usaha IK alas kaki Kabupaten dan Kota Bogor. Sebagian besar data primer berjenis informasi kualitatif. Sedangkan data sekunder pada penelitian ini menggunakan sebagian dari data Penelitian Strategis Nasional Direktorat Jenderal Pendidikan Tinggi, Kemendikbud, Tahun Anggaran 2012, dengan judul penelitian "Model Pengembangan Industri Kecil dan Rumah Tangga Alas Kaki dalam Menuju Keberlanjutan Usaha dan Menghadapi China Asean Free Trade Agreement (CAFTA)", yang umumnya berjenis kuantitatif.

Pemilihan contoh dilakukan dengan prosedur penarikan contoh non probabilitas dengan menggunakan metode purposive cluster sampling. Purposive sampling adalah teknik pengambilan sampel yang dilakukan secara sengaja dengan pertimbangan tertentu yang mencerminkan representasi terhadap populasi atau judgment para pakar untuk mencapai tujuan penelitian (Singarimbun dan Effendi 1995). Judgement yang dilakukan adalah melihat posisi Bogor sebagai salah satu sentra produksi alas kaki Indonesia, dimana perbandingan populasi antara pelaku usaha alas kaki di Kota dan Kabupaten Bogor adalah 1:3, sehingga contoh yang digunakan adalah 75 pelaku usaha di Kabupaten Bogor dan 25 pelaku usaha di Kota Bogor. Jumlah total contoh yang diteliti adalah 100 orang pelaku usaha yang mewakili industri kecil dan industri rumah tangga alas kaki di wilayah Bogor. Penetapan wilayah Kecamatan hingga Desa yang dipilih, didasarkan pada posisi wilayah tersebut sebagai daerah yang memiliki konsentrasi tinggi sebagai sentra produksi alas kaki di masing-masing Kota dan Kabupaten Bogor.

Pengumpulan data primer pada penelitian ini dilakukan dengan metode wawancara mendalam (indepth interview) melalui pendekatan Participatory Action Research (PAR), kepada pihak UPT dan beberapa pelaku usaha alas kaki setempat. Indepth interview secara partisipatif dilakukan untuk mengetahui berbagai permasalahan dan potensi yang ada secara obyektif, sehingga aspirasi dari stakeholder yang berperan terwakili. Data sekunder diperoleh dari sumber data pihak yang berwenang maupun sumber-sumber lainnya (buku, dokumen, dll). 


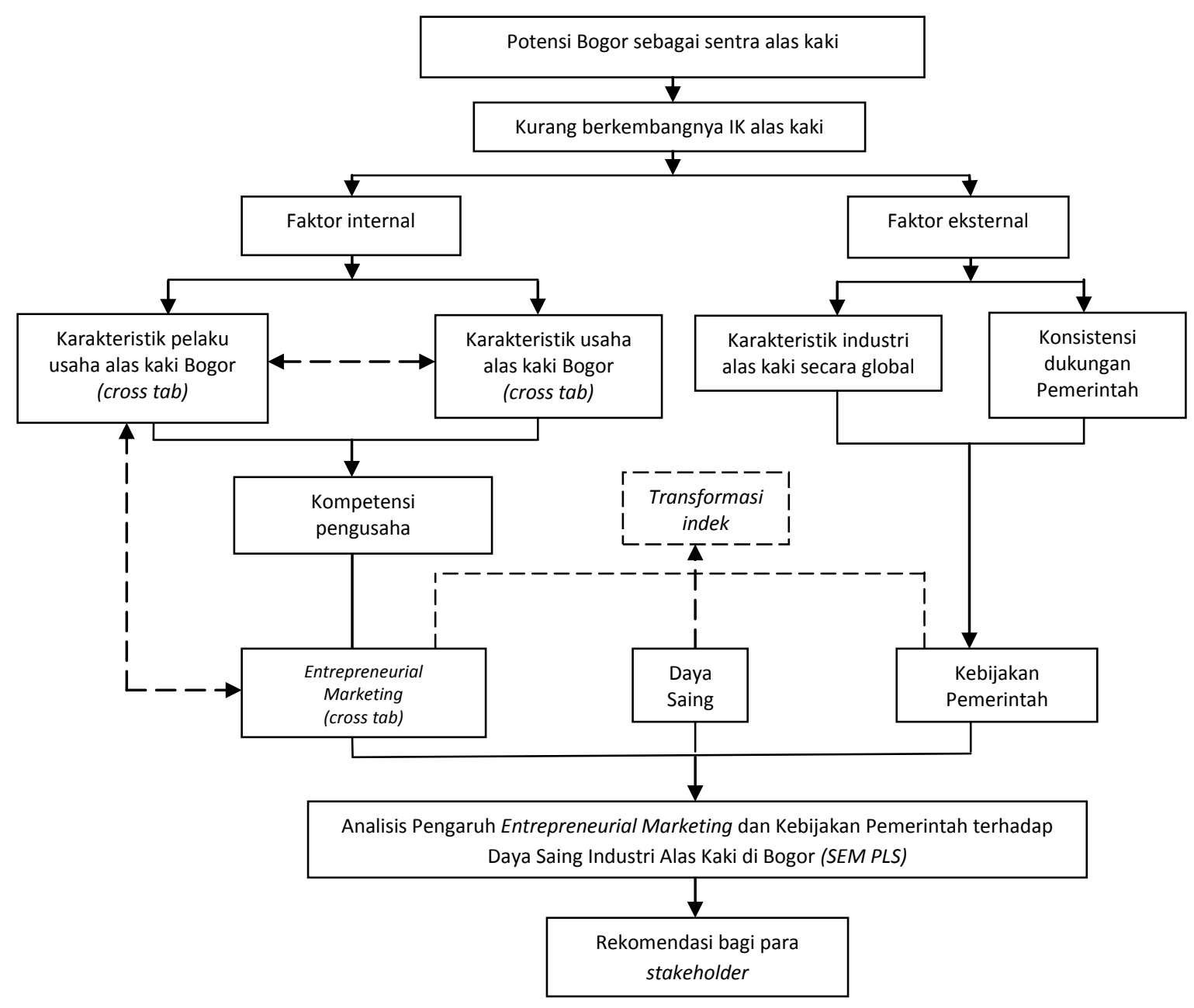

Gambar 2. Kerangka pemikiran penelitian

Pada penelitian ini digunakan skala Likert dengan jumlah empat skala. Hal ini mengikuti pernyataan Malhotra (2005) yang menyatakan bahwa, untuk menghindari kecenderungan responden menjawab netral yang menyebabkan bias tanggapan, maka skala dengan jumlah kategori genap dapat digunakan. Secara umum terdapat tiga analisis data pada penelitian ini, yaitu analisis deskriptif tabulasi silang, analisis transformasi indeks dan analisis SEM dengan pendekatan PLS.

Analisis deskriptif dilakukan pada data identitas responden, karakteristik pelaku usaha dan karakteristik usaha alas kaki di wilayah Bogor. Hasil dari analisis deskriptif tersebut dilanjutkan dengan analisis tabulasi silang untuk melihat keterkaitan antar peubah yang diukur.

Analisis transformasi indeks dilakukan pada data berskala Likert dari beberapa pertanyaan berikut: (1) pertanyaan yang mengukur kemampuan responden dalam hal entrepreneurial marketing, (2) pertanyaan yang mengukur sejauh mana implementasi kebijakan pemerintah yang dirasakan oleh responden, (3) dan pertanyaan mengenai kemampuan daya saing responden. Hasil dari analisis ini adalah tingkat indeks dalam persentase, yang mencerminkan pencapaian dari masing-masing peubah.

Analisis SEM dengan pendekatan PLS digunakan untuk melihat pengaruh langsung antar peubah entrepreneurial marketing dan kebijakan pemerintah terhadap daya 
saing IK alas kaki, serta pengaruh tidak langsung kebijakan pemerintah terhadap daya saing melalui entrepreneurial marketing. Berdasarkan hasil analisis SEM dengan pendekatan PLS, diperoleh berbagai indikator yang benar-benar kuat dalam menggambarkan masing-masing peubah latennya. Pendekatan PLS dipilih, karena merupakan metode analisis yang powerful karena dapat diterapkan pada semua jenis skala data (distribution free), dengan ukuran contoh tidak harus besar, dan cocok digunakan untuk model pengembangan.

Peubah yang diteliti dalam penelitian ini dioperasionalisasikan ke dalam dua peubah utama, yaitu peubah eksogen atau peubah independen dan peubah endogen atau peubah dependen. Peubah eksogen merupakan peubah yang mempengaruhi peubah lainnya, sedangkan peubah endogen adalah peubah yang posisinya dipengaruhi oleh peubah lainnya. Dikarenakan bentuk model penelitian yang berbentuk siklus, maka ada peubah yang dapat sekaligus menjadi peubah eksogen dan endogen.

Operasionalisasi peubah merupakan kegiatan menguraikan peubah menjadi sejumlah peubah operasional (indikator) yang menunjuk langsung pada hal-hal yang dapat diamati atau diukur. Secara lebih rinci operasionalisasi masing-masing peubah dalam penelitian ini ditunjukkan pada Tabel 2 - 4. 
98 | Septiani, Sarma, Limbong - Pengaruh Entrepreneurial Marketing

Tabel 2. Operasionalisasi peubah entrepreneurial marketing

\begin{tabular}{|c|c|c|c|c|}
\hline Peubah & Sub peubah & Definisi & Indikator & Skala \\
\hline \multirow{5}{*}{$\begin{array}{l}\text { Entrepreneuri } \\
\text {-al Marketing } \\
\text { (X1) }\end{array}$} & & \multicolumn{3}{|c|}{$\begin{array}{l}\text { "Entrepreneurial Marketing adalah pemasaran dari beberapa perusahaan keci } \\
\text { (IKM) yang berkembang melalui kewirausahaan" (Bjerke dan Hultman 2002) }\end{array}$} \\
\hline & Konsep & $\begin{array}{l}\text { Dalam hal orientasi bisnis, } \\
\text { kewirausahaan pemasaran } \\
\text { berfokus pada orientasi } \\
\text { inovasi dan keberadaan ide } \\
\text { serta intuisi sebagai alat } \\
\text { untuk menilai kebutuhan } \\
\text { pasar. } \\
\text { (Stokes 2000) }\end{array}$ & $\begin{array}{l}\text { - Tingkat kemampuan berkreasi } \\
\text { dalam produk } \\
\text { - Tingkat kemampuan berkreasi } \\
\text { dalam penjualan } \\
\text { - Tingkat intensitas penerapan } \\
\text { diversifikasi produk } \\
\text { - Tingkat frekuensi pencarian } \\
\text { informasi tentang jenis produk } \\
\text { baru } \\
\text { - Tingkat keragaman jenis } \\
\text { produk yang ada saat ini } \\
\text { - Tingkat intensitas pembuatan } \\
\text { model baru } \\
\text { - Tingkat kemampuan membaca } \\
\text { peluang pasar }\end{array}$ & Ordinal \\
\hline & Strategi & $\begin{array}{l}\text { Pada tingkat strategis, } \\
\text { kewirausahaan pemasaran } \\
\text { mempraktikkan proses } \\
\text { bottom-up atau } \\
\text { menyediakan produk sesuai } \\
\text { permintaan klien, konsep STP } \\
\text { tidak diterapkan oleh IKM, } \\
\text { karena target pasar dibentuk } \\
\text { dari proses eliminasi dan } \\
\text { seleksi alamiah oleh klien. } \\
\text { (Stokes 2000) }\end{array}$ & $\begin{array}{l}\text { - Tingkat frekuensi mengikuti } \\
\text { selera pelanggan } \\
\text { - Tingkat intensitas ekspansi } \\
\text { daerah pemasaran baru } \\
\text { dengan karakteristik yang sama }\end{array}$ & Ordinal \\
\hline & Metode & $\begin{array}{l}\text { Pada tingkat taktis, } \\
\text { kewirausahaan pemasaran } \\
\text { tidak cocok dalam } \\
\text { mengadopsi 4P/7P, karena } \\
\text { pengusaha mengadopsi } \\
\text { pendekatan pemasaran } \\
\text { interaktif atau berkontak } \\
\text { langsung dengan pelanggan } \\
\text { (Stokes 2000) }\end{array}$ & $\begin{array}{l}\text { - Tingkat kemampuan menjalin } \\
\text { interaksi serta komunikasi yang } \\
\text { baik dengan pelanggan yang } \\
\text { baru dikenal } \\
\text { - Tingkat kemampuan } \\
\text { meningkatkan interaksi serta } \\
\text { komunikasi yang baik dengan } \\
\text { pelanggan yang sudah lama } \\
\text { dikenal }\end{array}$ & Ordinal \\
\hline & $\begin{array}{l}\text { Inteligensi } \\
\text { Pasar }\end{array}$ & $\begin{array}{l}\text { Dalam hal pemantauan } \\
\text { lingkungan pemasaran, } \\
\text { kewirausahaan pemasaran } \\
\text { menggunakan metode } \\
\text { informal seperti pengamatan } \\
\text { pribadi atau menggunakan } \\
\text { jaringan informal yang ada. } \\
\text { (Stokes 2000) }\end{array}$ & $\begin{array}{l}\text { - Tingkat keluwesan sikap } \\
\text { terhadap pemasok } \\
\text { - Tingkat kemampuan } \\
\text { menciptakan hubungan baik } \\
\text { secara informal dengan Instansi } \\
\text { Pemerintah } \\
\text { - Tingkat kemampuan } \\
\text { menciptakan hubungan baik } \\
\text { secara informal dengan usaha } \\
\text { menengah } \\
\text { - Tingkat kemampuan } \\
\text { menciptakan hubungan baik } \\
\text { secara informal dengan usaha } \\
\text { besar } \\
\text { - Tingkat keaktifan mencari } \\
\text { informasi mengenai } \\
\text { perkembangan usaha yang } \\
\text { ditekuni }\end{array}$ & Ordinal \\
\hline
\end{tabular}

Sumber: Modifikasi peneliti dari berbagai literatur (2012) 
Tabel 3. Operasionalisasi peubah kebijakan pemerintah

\begin{tabular}{|c|c|c|c|c|}
\hline Peubah & Sub peubah & Definisi & Indikator & Skala \\
\hline \multirow[t]{6}{*}{$\begin{array}{l}\text { Kebijakan } \\
\text { Pemerinta } \\
\text { h (X2) }\end{array}$} & & \multicolumn{3}{|c|}{$\begin{array}{l}\text { "Kebijakan pemerintah adalah serangkaian keputusan yang ditetapkan } \\
\text { dan dilaksanakan oleh pemerintah yang memiliki tujuan tertentu demi } \\
\text { kepentingan publik" (Winarno 2002) }\end{array}$} \\
\hline & $\begin{array}{l}\text { Kebijakan } \\
\text { fasilitasi } \\
\text { permodalan }\end{array}$ & $\begin{array}{l}\text { Kebijakan yang berfokus } \\
\text { pada peran Pemerintah } \\
\text { dalam memfasilitasi akses } \\
\text { permodalan } \\
\text { (Kusumawati 2010) }\end{array}$ & $\begin{array}{l}\text { - Tingkat frekuensi pemerintah } \\
\text { memfasilitasi pinjaman modal }\end{array}$ & Ordinal \\
\hline & $\begin{array}{l}\text { Kebijakan } \\
\text { fasilitasi } \\
\text { pelatihan }\end{array}$ & $\begin{array}{l}\text { Kebijakan yang berfokus } \\
\text { pada peran Pemerintah } \\
\text { dalam menyediakan } \\
\text { berbagai bentuk pelatihan } \\
\text { (Kusumawati 2010) }\end{array}$ & $\begin{array}{l}\text { - Tingkat frekuensi pemerintah } \\
\text { menyelenggarakan pelatihan } \\
\text { manajerial } \\
\text { - Tingkat frekuensi pemerintah } \\
\text { menyelenggarakan pelatihan } \\
\text { marketing } \\
\text { - Tingkat frekuensi pemerintah } \\
\text { menyelenggarakan pelatihan } \\
\text { produksi } \\
\text { - Tingkat frekuensi pemerintah } \\
\text { menyelenggarakan pelatihan } \\
\text { keuangan }\end{array}$ & Ordinal \\
\hline & $\begin{array}{l}\text { Kebijakan } \\
\text { peraturan } \\
\text { kemudahan } \\
\text { investasi }\end{array}$ & $\begin{array}{l}\text { Kebijakan yang berisi } \\
\text { regulasi Pemerintah } \\
\text { dalam mendukung } \\
\text { keberlanjutan IK alas kaki. } \\
\text { (Kusumawati 2010) }\end{array}$ & $\begin{array}{l}\text { - Tingkat frekuensi penawaran } \\
\text { bantuan peralatan dari } \\
\text { pemerintah } \\
\text { - Tingkat frekuensi pemberian } \\
\text { fasilitas (pasar) bagi usaha } \\
\text { kecil oleh pemerintah }\end{array}$ & Ordinal \\
\hline & $\begin{array}{l}\text { Kebijakan } \\
\text { peraturan } \\
\text { persaingan } \\
\text { usaha }\end{array}$ & $\begin{array}{l}\text { Kebijakan yang berisi } \\
\text { regulasi Pemerintah } \\
\text { dalam mengendalikan } \\
\text { persaingan usaha alas } \\
\text { kaki } \\
\text { (Kusumawati 2010) }\end{array}$ & $\begin{array}{l}\text { - Tingkat frekuensi } \\
\text { pengendalian persaingan } \\
\text { antar usaha kecil oleh } \\
\text { pemerintah } \\
\text { - Tingkat frekuensi } \\
\text { pengendalian persaingan } \\
\text { antar usaha kecil dengan } \\
\text { usaha besar/menengah oleh } \\
\text { pemerintah }\end{array}$ & Ordinal \\
\hline & $\begin{array}{l}\text { Kebijakan } \\
\text { peraturan } \\
\text { kemudahan } \\
\text { prosedur izin }\end{array}$ & $\begin{array}{l}\text { Kebijakan yang berisi } \\
\text { regulasi Pemerintah } \\
\text { terkait proses pengajuan } \\
\text { berbagai izin usaha } \\
\text { (Kusumawati 2010) }\end{array}$ & $\begin{array}{l}\text { - Tingkat frekuensi pemerintah } \\
\text { dalam memberikan } \\
\text { kemudahan prosedur izin } \\
\text { bagi usaha kecil industri alas } \\
\text { kaki }\end{array}$ & Ordinal \\
\hline
\end{tabular}

Sumber: Modifikasi peneliti dari berbagai literatur (2012) 
Tabel 4. Operasionalisasi peubah daya saing

\begin{tabular}{|c|c|c|c|c|}
\hline \multirow{2}{*}{$\begin{array}{l}\text { Peubah } \\
\text { Daya Saing } \\
\text { (Y) }\end{array}$} & \multirow[t]{2}{*}{ Sub peubah } & Definisi & Indikator & Skala \\
\hline & & $\begin{array}{l}\text { "Daya saing adalah suatu } \\
\text { komitmen perusahaan-pe } \\
\text { (Tambunan 2010) }\end{array}$ & $\begin{array}{l}\text { konsep yang biasanya me } \\
\text { usahaan terhadap persa }\end{array}$ & $\begin{array}{l}\text { ujuk kepada } \\
\text { gan pasar" }\end{array}$ \\
\hline & $\begin{array}{l}\text { Pangsa } \\
\text { pasar dalam } \\
\text { negeri }\end{array}$ & $\begin{array}{l}\text { Komitmen terhadap } \\
\text { persaingan pasar dalam } \\
\text { konteks daya saing IK, } \\
\text { terkait pangsa pasar yang } \\
\text { dimiliki } \\
\text { (Tambunan 2010) }\end{array}$ & $\begin{array}{l}\text { - Tingkat kemampuan } \\
\text { bersaing dengan usaha } \\
\text { lain sejenis } \\
\text { - Tingkat penambahan } \\
\text { jumlah pelanggan setiap } \\
\text { tahunnya }\end{array}$ & Ordinal \\
\hline & $\begin{array}{l}\text { Diversifikasi } \\
\text { pasar } \\
\text { domestik }\end{array}$ & $\begin{array}{l}\text { Komitmen terhadap } \\
\text { persaingan pasar dalam } \\
\text { konteks daya saing IK, } \\
\text { terkait diversifikasi pasar } \\
\text { domestik (Tambunan } \\
\text { 2010) }\end{array}$ & $\begin{array}{l}\text { - Tingkat perkembangan } \\
\text { wilayah pemasaran di } \\
\text { berbagai daerah }\end{array}$ & Ordinal \\
\hline & Nilai produk & $\begin{array}{l}\text { Komitmen terhadap } \\
\text { persaingan pasar dalam } \\
\text { konteks daya saing } \\
\text { produk, terkait nilai jual } \\
\text { produk } \\
\text { (Tambunan 2010) }\end{array}$ & $\begin{array}{l}\text { - Tingkat keberhasilan } \\
\text { produk dijual pada } \\
\text { pelanggan baru }\end{array}$ & Ordinal \\
\hline & $\begin{array}{l}\text { Kepuasan } \\
\text { konsumen } \\
\text { terhadap } \\
\text { produk }\end{array}$ & $\begin{array}{l}\text { Komitmen terhadap } \\
\text { persaingan pasar dalam } \\
\text { konteks daya saing } \\
\text { produk, dalam } \\
\text { memberikan kepuasan } \\
\text { bagi konsumen } \\
\text { (Tambunan 2010) }\end{array}$ & $\begin{array}{l}\text { - Tingkat kesenangan } \\
\text { konsumen terhadap } \\
\text { produk yang dibeli }\end{array}$ & Ordinal \\
\hline
\end{tabular}

Sumber: Modifikasi peneliti dari berbagai literatur (2012)

\section{Hasil dan Pembahasan}

III.1. Identitas Pelaku Usaha

Sebagian besar pemilik usaha alas kaki di wilayah Bogor berjenis kelamin laki-laki (92\%). Berdasarkan observasi lapangan diketahui bahwa usaha alas kaki sebagian besar diminati oleh para lelaki, karena banyaknya para lelaki yang bekerja di bengkel-bengkel alas kaki, sebelum mendirikan usaha secara mandiri. Usaha alas kaki telah dijadikan usaha pokok oleh sebagian besar pengrajin lama, terbukti $43 \%$ pengrajin berusia lebih dari 40-50 tahun. Namun, persentase pelaku usaha yang berusia produktif juga tidak kalah besarnya (42\%) dengan kisaran usia antara 30 tahun hingga 40 tahun. Berdasarkan judgement bahwa perbandingan populasi pelaku usaha Kota dan Kabupaten Bogor adalah 1:3, dimana wilayah penelitian difokuskan pada wilayah dengan konsentrasi tinggi sebagai sentra produksi alas kaki di Bogor, maka ditetapkan bahwa mayoritas industri kecil alas kaki terdapat di Kabupaten Bogor, Kecamatan Ciomas, Desa Parakan dengan persentase masing-masing 75\%. 


\section{III.2. Karakteristik Pelaku Usaha}

Pada umumnya, pelaku usaha alas kaki Bogor merupakan lulusan Sekolah Dasar/Madrasah Ibtidaiyah (SD/MI) (47\%). Hal ini sesuai dengan rataan lama sekolah pelaku usaha alas kaki yang baru mencapai enam tahun. Para pelaku usaha alas kaki yang ada di wilayah Bogor sebagian besar (48\%) adalah mantan buruh di bengkelbengkel sepatu/sandal. Dengan bermodalkan pengalaman yang dimiliki dan keyakinan bahwa usaha alas kaki berpotensi menguntungkan, membuatnya beralih untuk mendirikan usaha alas kaki secara mandiri. Di sisi lain, potensi usaha alas kaki telah jauh disadari oleh beberapa pelaku usaha, dimana $45 \%$ pelaku usaha alas kaki menjadikan usahanya sebagai pekerjaan pertama dan utama.

Mayoritas latar belakang menjalankan usaha alas kaki sebagai keinginan sendiri (65\%). Karakter usaha alas kaki sebagai usaha turun temurun tidak nyata, terlihat pada penelitian ini. $73 \%$ pelaku usaha memulai usahanya dengan tidak mengikuti keluarga atau murni merintisnya sendiri. Hal ini dapat terjadi karena sebagian besar (26\%) dari pelaku usaha sudah memiliki kemampuan membaca peluang yang menguntungkan pada usaha ini. Meski para pelaku usaha alas kaki acap kali menghadapi kesulitan dalam menjalankan usahanya, keyakinan terhadap potensi menguntungkan pada usaha ini membuat mayoritas darinya jarang (37\%) bahkan tidak pernah (27\%) berkeinginan untuk pindah dari usaha ini. Keterbatasan modal dan lama usaha yang dijalankan, telah membentuk pola pikir pelaku usaha alas kaki Bogor yang masih berorientasi jangka pendek, dimana 76\% darinya mengaku tidak pernah keluar daerah dalam menjalankan usahanya.

\section{III.3. Karakteristik Usaha}

Mayoritas pelaku usaha menjalankan usahanya sudah lebih dari 10 tahun (52\%). Meski demikian, jenis usaha pada industri alas kaki di wilayah Bogor masih tergolong pada industri kecil (54\%). Hal ini sesuai dengan rataan jumlah pekerja yang dimiliki pelaku usaha sekitar lima orang pekerja, waktu kerja 8-12 jam kerja per hari, dengan omset rataan 100-250 kodi per bulan (53\%). Jenis usaha yang masih tergolong IK, maka mayoritas darinya mengalami kekurangan dalam alat produksi (58\%), modal (51\%) dan sumber daya manusia (64\%).

Usaha alas kaki memiliki posisi yang berbeda-beda bagi para pelakunya. Berdasarkan data yang diperoleh diketahui bahwa, usaha alas kaki ini sangat menjadi sumber utama pendapatan keluarganya (70\%). Hal ini dapat dimengerti karena sebagian besar pelaku usaha alas kaki, yaitu 87 persen darinya tidak memiliki usaha lain atau usaha sampingan. Usaha alas kaki di wilayah Bogor juga merupakan tumpuan hidup bagi mayoritas pelakunya, sebagian besar pelaku usaha (67\%) menyatakan bahwa sekitar 76-100\% kebutuhan keluarga, terpenuhi melalui pendapatan dari usaha alas kaki.

\section{III.4. Hubungan Karakteristik Pelaku Usaha dan Karakteristik Usaha}

Berdasarkan hasil analisis tabulasi silang (cross tabulation), maka dapat diketahui hubungan beberapa faktor karakteristik pelaku usaha dan karakteristik usaha alas kaki di Bogor (Tabel 5). Keberadaan hubungan antar peubah yang diukur dapat terlihat dari nilai nyatanya untuk masing-masing faktor. 
Tingkat pendidikan pelaku usaha memiliki hubungan dengan jenis usaha dan perolehan omset $(\mathrm{Rp})$ rataan per bulan. Semakin tinggi tingkat pendidikan pelaku usaha, akan semakin memiliki kecenderungan untuk mengembangkan usahanya pada tingkat yang lebih besar. Para pelaku usaha yang tidak tamat sekolah mayoritas menjalankan usahanya pada kategori industri rumah tangga, sedangkan bagi yang berpendidikan lebih tinggi, yaitu lulusan SD/MI atau hingga Perguruan Tinggi (PT) umumnya menggeluti usaha pada kategori industri kecil, yang beroperasi dengan jumlah tenaga kerja yang lebih banyak daripada industri rumah tangga.

Tabel 5. Signifikansi hubungan karakteristik pelaku usaha dan karakteristik usaha

\begin{tabular}{llccc}
\hline No. & \multicolumn{1}{c}{ Faktor } & $\begin{array}{c}\text { Approx. Sig. Spearman } \\
\text { Correlation }\end{array}$ & $\begin{array}{c}\text { Approx. Sig. } \\
\text { Pearson's R }\end{array}$ & $\begin{array}{c}\text { Interpretasi } \\
(\mathbf{\alpha}=\mathbf{0 , 0 5})\end{array}$ \\
\hline 1. & $\begin{array}{l}\text { Tingkat pendidikan: } \\
\text { * Jenis usaha }\end{array}$ & 0,044 & 0,027 & Ada hubungan nyata \\
& * Omset (Rp) & 0,047 & 0,038 & \\
2. $\quad \begin{array}{l}\text { Kepemilikan modal: } \\
\text { * Keinginan pindah usaha }\end{array}$ & 0,022 & 0,013 & Ada hubungan nyata \\
3. & $\begin{array}{l}\text { Omset (Rp): } \\
\text { * Terpenuhi kebutuhan }\end{array}$ & 0,001 & 0,004 & Ada hubungan nyata \\
\hline
\end{tabular}

Sumber: Data sekunder, diolah (2012)

Selanjutnya, tingkat pendidikan juga memiliki hubungan nyata dengan omset (Rp), dimana jumlah omset (Rp) berkaitan dengan kapasitas dan jenis usaha yang dijalani. Bagi pelaku usaha yang tidak tamat sekolah, perolehan omset (Rp) rataan per bulan adalah kurang dari 10 juta. Bagi yang berpendidikan SD/MI dan Sekolah Menengah Pertama/Madrasah Tsanawiyah (SMP/MTs), umumnya memiliki omset (Rp) rataan per bulan lebih dari 10-30 juta. Sedangkan para pelaku usaha dengan tingkat pendidikan Sekolah Menengah Atas/Madrasah Aliyah (SMA/SMK/MA) atau PT, mayoritas memiliki omset (Rp) lebih dari 30 hingga 60 juta per bulannya. Hal ini semakin menguatkan pernyataan bahwa, tingkat pendidikan pelaku usaha memiliki peranan penting dalam menunjang perkembangan usahanya. Meski demikian faktanya masih banyak pengusaha yang belum mencapai jenjang pendidikan yang lebih tinggi. Oleh karenanya, keaktifan dalam mengikuti kegiatan pelatihan yang diadakan Pemda setempat, setidaknya dapat menanggulangi hal tersebut. Melalui berbagai pelatihan, para pengusaha dapat mengambil beberapa manfaat seperti, dapat meningkatkan mindset dalam berusaha hingga mampu berinteraksi dengan usaha yang berskala lebih besar lewat networking Pemda setempat. Keaktifan pengusaha dalam mengikuti berbagai pelatihan memberi konsekuensi pada pihak Pemda setempat untuk memberikan kegiatan pelatihan yang lebih optimal yang disertai monev dan pembinaan intensif pasca pelatihan.

Hubungan nyata terlihat pada tingkat omset (Rp) rataan per bulan dengan persentase terpenuhinya kebutuhan keluarga pelaku usaha. Bagi mereka yang beromset kurang dari Rp 10 juta per bulannya mayoritas dapat memenuhi kebutuhan keluarga hanya 51-75\%. Sedangkan bagi pelaku usaha yang memiliki omset lebih dari Rp 10 juta-Rp 100 juta per bulan, umumnya mampu memenuhi kebutuhan keluarganya pada kisaran $76-100 \%$. Melalui perolehan omset (Rp) rataan per bulan yang semakin besar, maka pelaku usaha memiliki kecenderungan semakin mampu 
dalam memenuhi kebutuhan keluarganya. Keterbatasan modal menyebabkan sebagian besar pelaku usaha masih mengikuti sistem bon putih, dimana posisi tawar mereka menjadi sangat lemah. Kemandirian modal merupakan hal yang dapat menigkatkan posisi tawar pelaku usaha dalam industri ini. Dalam rangka menuju kemandirian modal, pelaku usaha harus menyiapkan berbagai persyaratan yang diperlukan untuk pengajuan modal melalui pelatihan keuangan.

\section{III.5. Analisis Index Transformation Mengenai Kemampuan Entrepreneurial Marketing,} Implementasi Kebijakan Pemerintah, dan Kemampuan Daya Saing

Berdasarkan analisis transformasi indek, diketahui bahwa kemampuan entrepreneurial marketing pelaku usaha alas kaki di wilayah Bogor mencapai $61 \%$. Hal ini mengindikasikan bahwa pelaku usaha yang bertindak sebagai pengrajin memiliki potensi untuk berkembang menjadi mandiri. Kemampuan methods yang memfokuskan pada pendekatan pemasaran interaktif atau berkontak langsung dengan pelanggan, merupakan kemampuan entrepreneurial marketing terbesar yang dimiliki pelaku usaha alas kaki, yaitu 71\% (Gambar 3). Dalam melakukan usahanya, para pelaku usaha alas kaki selalu berkontak langsung dengan konsumennya, baik konsumen ritel maupun industri. Sebagian besar dari pelaku usaha melakukan sistem pemasaran direct selling untuk menjual produk mereka. Berbeda dengan ketiga kemampuan entrepreneurial marketing, kemampuan market intelligence masih relatif rendah. Sebagian besar pengusaha IKM jarang memiliki akses yang baik dengan Pemda setempat apalagi usaha yang berskala lebih besar. Hal ini sebenarnya dapat teratasi dengan keikutsertaan pengusaha pada berbagai kegiatan pelatihan yang diadakan Pemda. Para pelaku usaha juga dapat melakukan penguatan jaringan informal dengan stakeholder pada industri ini, sehingga berbagai informasi perkembangan pasar terkini dapat diperoleh dengan mudah.

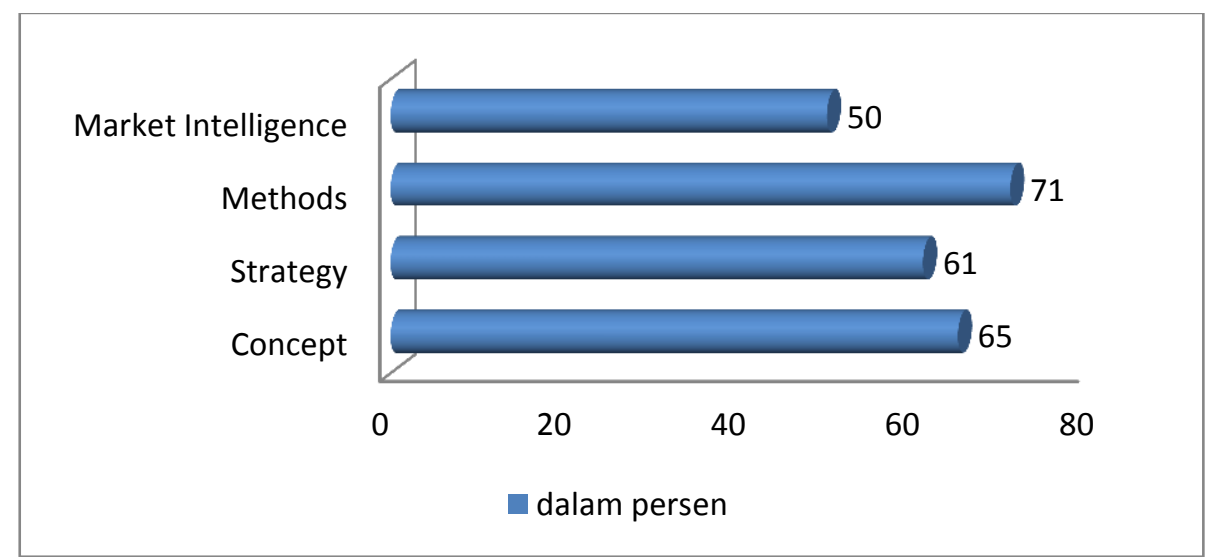

Gambar 3. Indeks entrepreneurial marketing (Data diolah, 2012)

Mayoritas pelaku indutri kecil alas kaki di wilayah Bogor masih belum merasakan implementasi dari kebijakan pemerintah daerah. Hal ini tercermin dari hasil analisis indeks yang menunjukkan bahwa kebijakan pemerintah yang dirasakan pelaku usaha alas kaki baru mencapai 32\%. Jika ditelusuri berdasarkan dimensinya, implementasi kebijakan pemerintah yang paling terasa di kalangan pelaku usaha alas kaki adalah kebijakan kemudahan prosedur izin usaha yaitu 61\% (Gambar 4). Hal ini disebabkan 
oleh beberapa hal diantaranya adalah kemunculan Badan Perizinan Terpadu (BPT) yang mengakomodir izin usaha secara terpusat dan praktis. Di sisi lain, berbagai kebijakan Pemda yang dirasa belum optimal perlu untuk segera ditindaklanjuti. Mulai dari kegiatan pelatihan yang lebih efektif, penyediaan pasar yang pasti bagi pelaku usaha, penguatan Kelompok Usaha Bersama (KUB), sosialisasi keberadaan dan fungsi UPT, hingga membukakan jalan untuk bekerjasama dengan pihak bank atau swasta, menjadi poin-poin penting yang harus dilakukan oleh Pemda.

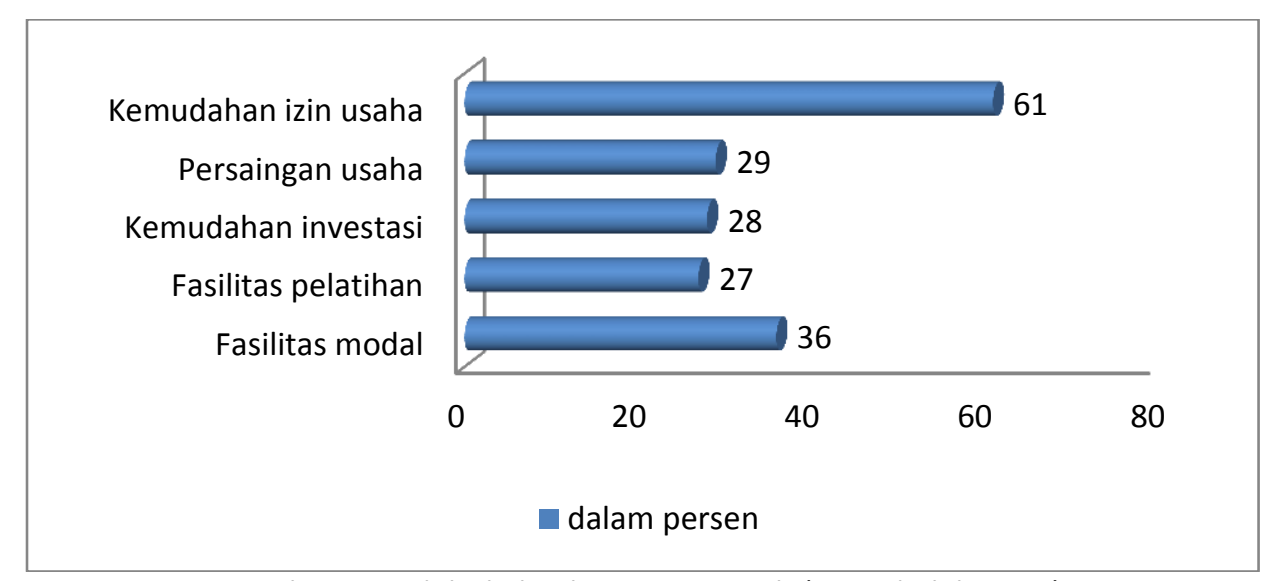

Gambar 4. Indeks kebijakan pemerintah (Data diolah 2012)

Meski menghadapi berbagai macam kendala dalam industri alas kaki, secara umum pelaku usaha alas kaki di wilayah Bogor memiliki kemampuan daya saing yang baik. Kemampuan daya saing secara keseluruhan terlaksana pada tingkat $66 \%$. Indikator kemampuan daya saing yang paling besar tercermin pada daya saing produk, dimana produk alas kaki para pelaku usaha telah mampu membentuk kepuasan konsumennya (75\%) (Gambar 5). Hal ini dapat dipahami mengingat produk-produk yang dihasilkan para pelaku usaha alas kaki Bogor adalah produk bermutu baik, sehingga menimbulkan perasaan senang pada konsumen yang membeli produk alas kaki Bogor, dan pada akhirnya membentuk kepuasan konsumen.

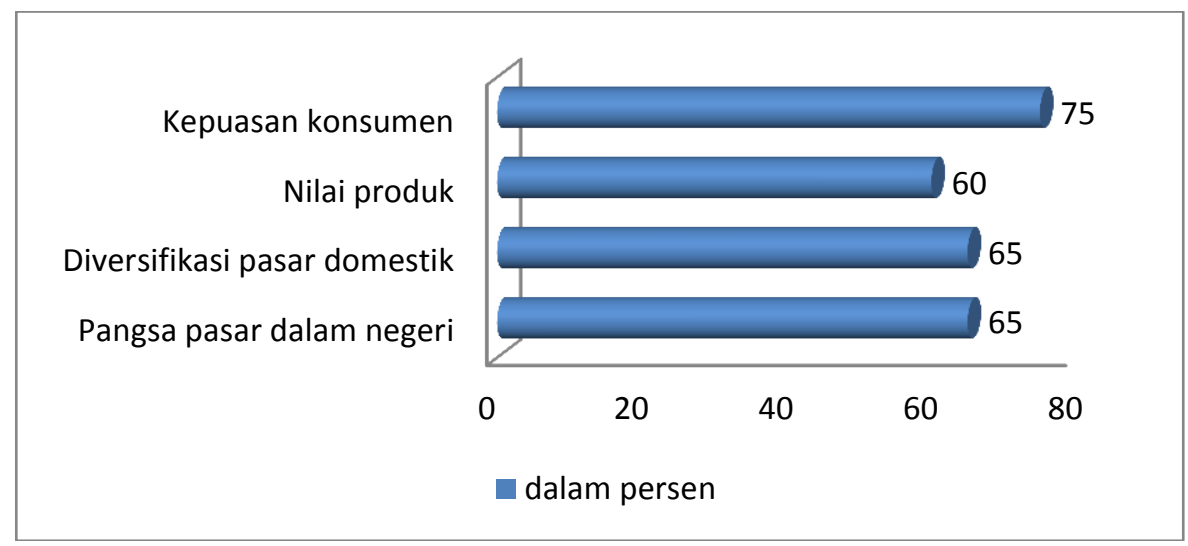

Gambar 5. Indeks daya saing (Data diolah 2012) 
III.6. Analisis SEM-PLS Entrepreneurial Marketing dan Kebijakan Pemerintah terhadap

Daya Saing Industri Alas Kaki di Bogor

Peubah laten dalam penelitian ini terdiri dari tiga peubah, yaitu entrepreneurial marketing (EM), kebijakan pemerintah (KP) dan daya saing (DS). Setiap peubah laten memiliki masing-masing peubah manifest (indikator) sesuai dengan yang dijabarkan pada operasionalisasi peubah sebelumnya. Kode angka pada indikator menunjukkan nomor pertanyaan kuesioner. Selanjutnya, pada analisis SEM PLS akan dilakukan dua analisis model yaitu, analisis outer model dan analisis inner model.

\section{III.7. Analisis Outer Model}

Pengujian mode reflektif terlebih dahulu dilakukan dengan menggunakan lima kriteria yaitu, Loading factor, Composite Reliability, Average Variance Extracted (AVE), Akar kuadrat AVE, dan Cross Loading (Ghozali 2008). Berdasarkan Tabel 6, diketahui bahwa model ini telah memenuhi nilai standar pada setiap kriteria outer model yang ada. Sehingga, dapat dikatakan bahwa model ini memiliki validitas dan reliabilitas yang baik.

Tabel 6. Hasil penilaian kriteria dan standar nilai mode reflektif (direct effect EM terhadap DS dan indirect effect KP terhadap DS melalui EM)

\begin{tabular}{|c|c|c|c|c|}
\hline No. & Kriteria & Penjelasan & Standar & Hasil penilaian \\
\hline 1. & Loading factor & $\begin{array}{l}\text { Kekuatan } \\
\text { indikator dalam } \\
\text { merefleksikan } \\
\text { laten }\end{array}$ & $\geq 0,6$ & $\begin{array}{l}\text { Semua indikator memiliki } \\
\text { loading factor } \geq 0,6\end{array}$ \\
\hline 2. & $\begin{array}{l}\text { Composite } \\
\text { Reliability }\end{array}$ & $\begin{array}{l}\text { Konsistensi } \\
\text { internal }\end{array}$ & $>0,6$ & $\begin{array}{l}\mathrm{EM}=0,843 ; \mathrm{KP}=0,882 ; \mathrm{DS} \\
=0,775\end{array}$ \\
\hline 3. & AVE & Validitas konstruk & $>0,5$ & $\begin{array}{l}\mathrm{EM}=0,518 ; \mathrm{KP}=0,604 ; \mathrm{DS} \\
=0,538\end{array}$ \\
\hline 4. & Akar kuadrat AVE & $\begin{array}{l}\text { Validitas } \\
\text { diskriminan }\end{array}$ & $\begin{array}{l}\text { Lebih besar dari nilai } \\
\text { korelasi antar peubah }\end{array}$ & $\begin{array}{l}\text { Semua nilai akar kuadrat } \\
\text { AVE dari peubah laten, } \\
\text { lebih besar dari korelasi } \\
\text { peubah laten lainnya. }\end{array}$ \\
\hline 5. & Cross Loading & $\begin{array}{l}\text { Validitas } \\
\text { diskriminan }\end{array}$ & $\begin{array}{l}\text { Setiap indikator } \\
\text { memiliki loading } \\
\text { lebih tinggi untuk } \\
\text { setiap laten yang } \\
\text { diukur, dibandingkan } \\
\text { dengan indikator } \\
\text { untuk laten lainnya }\end{array}$ & $\begin{array}{l}\text { Semua indikator EM, KP } \\
\text { dan DS memiliki korelasi } \\
\text { yang lebih besar pada laten } \\
\text { sendiri daripada korelasi ke } \\
\text { laten lainnya. }\end{array}$ \\
\hline
\end{tabular}

Sumber: Data sekunder, diolah (2012)

Berdasarkan Gambar 6 diketahui bahwa, peubah laten entrepreneurial marketing (EM) dicerminkan oleh lima indikator utama, X1.30: frekuensi diversifikasi produk $(0,723), X 1.32$ : tingkat keragaman produk $(0,693), X 1.41$ : kemampuan menjalin hubungan dengan usaha menengah $(0,759), \mathrm{X} 1.42$ : kemampuan menjalin hubungan dengan usaha besar $(0,712)$, dan X1.43: tingkat keaktifan mencari info usaha $(0,710)$. Berdasarkan persepsi pelaku usaha, kemampuan entrepreneurial marketing yang berkaitan dengan daya saing dicerminkan dominan oleh sub peubah concept (frekuensi diversifikasi produk dan tingkat keragaman produk) dan market intelligence 
(kemampuan menjalin hubungan dengan usaha menengah, kemampuan menjalin hubungan dengan usaha besar dan tingkat keaktifan mencari info usaha). Sub peubah concept menjelaskan mengenai inovasi dan diversifkasi produk, sedangkan market intelligence berkaitan dengan jaringan informal dan pengumpulan informasi pasar.

Dalam hal inovasi dan diversifikasi produk, sebagian besar pelaku usaha alas kaki telah piawai melakukannya. Mayoritas darinya membeli buku-buku desain alas kaki atau majalah, untuk mencari model alas kaki terkini. Ada juga yang mendatangi sejumlah outlet-outlet alas kaki tertentu, hanya sekedar untuk melihat variasi model alas kaki di pasaran. Bahkan, bagi sejumlah pelaku usaha yang cukup berkembang, menggunakan akses internet untuk benchmarking dan memunculkan ide-ide baru dalam berinovasi.

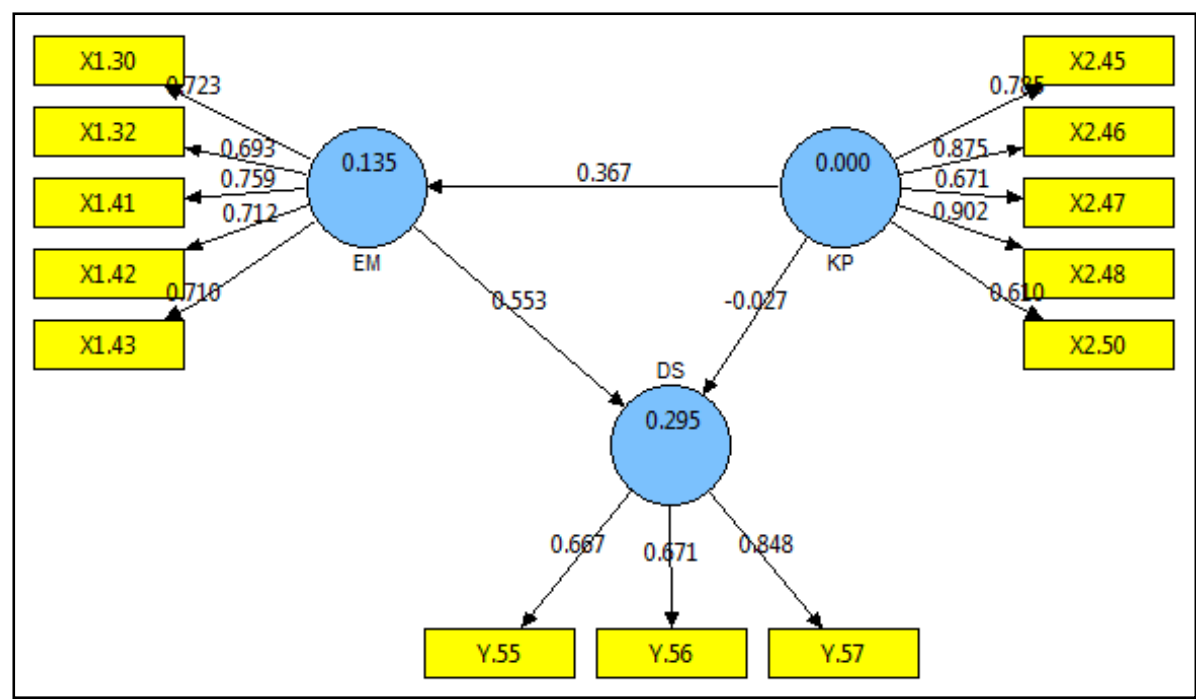

Gambar 6. Model akhir (indirect effect dan full sample)

Di sisi lain, kebijakan pemerintah yang baik dicerminkan setidaknya oleh lima indikator utama. Selain dimensi kebijakan pelatihan (X2.45: frekuensi pelatihan manajerial, X2.46: frekuensi pelatihan marketing, X2.47: frekuensi pelatihan produksi dan X2.48: frekuensi pelatihan keuangan), kebijakan pemerintah terkait kemudahan investasi khususnya pemberian fasilitas atau pasar (X2.50) merupakan indikator dominan yang setidaknya perlu dilakukan dengan optimal dalam rangka mencerminkan intervensi efektif dari pihak pemerintah.

Pada kenyataannya, pemerintah belum optimal dalam merealisasikan kebijakankebijakannya yang berkaitan dengan pelatihan dan pemberian pasar. Pada umumnya, pelaku usaha masih belum merasakan keberadaan fungsi koperasi dan UPT yang notabenenya berperan dalam hal fasilitas dan pasar. Restrukturisasi koperasi dan keberadaan UPT yang belum cukup lama berdiri, menjadi penyebab terjadinya hal tersebut. Hasil interview menunjukkan bahwa sebagian besar pelaku usaha yang berkeinginan untuk menjalankan usahanya secara mandiri, maka masih memiliki kekhawatiran terhadap penyerapan produknya di pasaran. Pemberian pasar yang pasti dan fasilitas yang memadai dari pemerintah, merupakan tindakan proteksi terhadap keberlangsungan IK alas kaki, yang pada akhirnya mampu mendorong kemandirian usaha pada pelaku usaha setempat. 
Selanjutnya, kemampuan daya saing yang baik dapat dicirikan setidaknya dengan pencapaian tiga indikator utama, yaitu, Y.55 (peningkatan jumlah pelanggan per tahun), Y.56 (peningkatan cakupan wilayah pemasaran), dan Y.57 (tingkat keberhasilan produk terjual pada pelanggan baru). Keberhasilan produk terjual di pelanggan baru merupakan cerminan utama dari kemampuan berdaya saing. Ukuran indikator ini berkaitan dengan tingkat penerimaan konsumen baru terhadap model-model alas kaki yang ditawarkan pelaku usaha.

\section{III.8. Analisis Inner Model}

Pada analisis model inner, pengujian dilakukan terhadap dua kriteria yaitu: $\mathrm{R}^{2}$ dari peubah laten endogen dan estimasi koefisien jalur (Ghozali, 2008). Hasil pengolahan data menunjukkan bahwa, model pengaruh KP terhadap EM menghasilkan $\mathrm{R}^{2}$ sebesar 0,135 yang berarti, variabilitas laten EM dapat dijelaskan oleh variabilitas laten KP sebesar $13,5 \%$. Sedangkan model pengaruh EM dan KP terhadap DS memiliki nilai $\mathrm{R}^{2}$ sebesar 0,295 atau variabilitas laten DS dapat dijelaskan oleh variabilitas laten EM dan KP sebesar 29,5\%. Selengkapnya analisis inner model dapat dilihat pada Tabel 7.

Tabel 7. Nilai analisis model inner vs standar (direct effect EM terhadap DS dan indirect effect KP terhadap DS melalui EM)

\begin{tabular}{|c|c|c|c|c|}
\hline No. & Kriteria & Penjelasan & Standar & Hasil penilaian \\
\hline 1. & $\begin{array}{l}\mathrm{R}^{2} \text { dari peubah } \\
\text { laten endogen }\end{array}$ & $\begin{array}{l}\text { Variabilitas konstruk } \\
\text { endogen yang dapat } \\
\text { dijelaskan oleh } \\
\text { variabilitas konstruk } \\
\text { eksogen }\end{array}$ & $\begin{array}{l}\text { Chin (1998) } \\
\text { mengelompokkan nilai } \\
\mathrm{R}^{2} \text { 0,67; 0,33; dan 0,19 } \\
\text { sebagai "substansial", } \\
\text { "moderat" dan "lemah" }\end{array}$ & $\begin{array}{l}R^{2} \text { untuk } E M=0,135 \\
R^{2} \text { untuk } D S=0,295\end{array}$ \\
\hline 2. & $\begin{array}{l}\text { Estimasi } \\
\text { koefisien jalur }\end{array}$ & $\begin{array}{l}\text { Evaluasi terhadap } \\
\text { nilai koefisien, } \\
\text { meliputi pengaruh } \\
\text { nyata melalui } \\
\text { Bootstrap dan } \\
\text { besarnya nilai } \\
\text { koefisien }\end{array}$ & $\begin{array}{l}\text { Pengaruh nyata jika, t- } \\
\text { statistik > t-tabel. Pada } \\
\text { alpha } 5 \text { persen, nilai t- } \\
\text { tabel adalah } 1,96\end{array}$ & $\begin{array}{l}\text { Nilai t-statistik: } \\
\text { KP }>\text { EM }=6,428 \\
\text { EM }>\text { DS }=9,606 \\
\text { KP }>\text { DS }=0,390 \\
\text { Nilai koefisien: } \\
\text { KP }>\text { EM }=0,367 \\
E M->D S=0,553 \\
\text { KP }>\text { DS }=-0,027\end{array}$ \\
\hline
\end{tabular}

Sumber: Data sekunder, diolah (2012)

Berdasarkan hasil pengolahan data tersebut, diketahui bahwa tidak terdapat pengaruh nyata antara KP terhadap DS, dimana nilai t-statistik yang diberikan hanya sebesar 0,390 (lebih kecil dari nilai t-tabel), sehingga hipotesis 2 pada penelitian ini ditolak. Di sisi lain, pengaruh nyata terdapat pada 2 path lainnya, yaitu, pengaruh KP terhadap EM dengan nilai t-statistik 6,428 dan pengaruh EM terhadap DS dengan nilai t-statistik sebesar 9,606. KP berpengaruh secara tidak langsung terhadap DS melalui EM, maka kebijakan pemerintah sebaiknya lebih ditujukkan untuk meningkatkan kemampuan entrepreneurial marketing, daripada yang berkaitan langsung terhadap kemampuan daya saing.

Besarnya pengaruh laten eksogen terhadap laten endogen dapat dilihat dari besaran nilai koefisien jalur, yaitu pengaruh KP terhadap EM memberikan nilai koefisien positif 0,367, maka hipotesis 3 dapat diterima. Sedangkan pengaruh EM 
terhadap DS memiliki nilai koefisien positif lebih besar, yaitu 0,553, berarti hipotesis 1 diterima. Hasil tersebut dapat diartikan bahwa, ketika terjadi optimasi yang baik dalam kebijakan pemerintah, sehingga meningkatkan kemampuan entrepreneurial marketing $36,7 \%$. Selanjutnya, ketika terjadi kemajuan dalam hal kemampuan entrepreneurial marketing, maka akan meningkatkan kemampuan daya saing 55,3\%. Hasil analisis ini menunjukkan bahwa keberadaan entrepreneurial marketing para pelaku usaha kecil alas kaki yang didukung dengan kebijakan pemerintah secara optimal, akan berpengaruh besar terhadap kemampuan daya saing dalam pengembangan industri alas kaki Bogor.

\section{III.9. Implikasi Manajerial}

Kemampuan entrepreneurial marketing pelaku usaha dikatakan baik jika setidaknya telah tercapai optimalisasi pada lima indikator utama, yaitu, frekuensi diversifikasi produk, tingkat keragaman produk, kemampuan menjalin hubungan dengan usaha menengah, kemampuan menjalin hubungan dengan usaha besar, dan tingkat keaktifan mencari info usaha. Mengacu pada hasil analisis yang menunjukkan bahwa kebijakan pemerintah berpengaruh tidak langsung terhadap daya saing melalui kemampuan entrepreneurial marketing, maka pemerintah sebaiknya lebih memfokuskan intervensinya untuk meningkatkan kemampuan entrepreneurial marketing pelaku usaha, dibandingkan kemampuan daya saingnya.

Bagi pelaku usaha, perbaikan dalam hal kemampuan entrepreneurial marketing dikatakan berhasil apabila terjadi peningkatan kemampuan daya saing, yang dapat tercermin dari beberapa indikator dominan seperti: peningkatan jumlah pelanggan per tahun, peningkatan cakupan wilayah pemasaran dan tingkat keberhasilan produk terjual pada pelanggan baru.

Di sisi lain, berdasarkan persepsi pelaku usaha, kebijakan pemerintah dapat dikatakan baik jika minimal tercapainya 5 indikator utama seperti: pelatihan manajerial, pelatihan marketing, pelatihan produksi, pelatihan keuangan dan pemberian fasilitas atau pasar. Pelaksanaan dimensi kebijakan pelatihan diarahkan untuk membenahi kompetensi pelaku usaha, baik dari segi teknis maupun manajerial. Sedangkan kebijakan kemudahan investasi khususnya penyediaan pasar, merupakan salah satu bentuk proteksi yang dilakukan pemerintah dalam menjaga kemandirian usaha yang ada melalui penyerapan produk di pasaran. Dinas Perindustrian dan Perdagangan, Badan Perizinan Terpadu serta bidang UMKM merupakan beberapa instansi pemerintah yang bertanggung jawab terhadap fasilitasi pemasaran dan promosi produk-produk IKM lokal termasuk produk IK alas kaki. Oleh karena itu, fungsi dan keberadaan intervensi lintas sektoral untuk memajukan alas kaki Bogor perlu ditingkatkan. 
Tabel 8. Implikasi manajerial

\begin{tabular}{|c|c|c|c|}
\hline Stakeholder & Perencanaan & Pelaksanaan & Pengendalian \\
\hline \multirow[t]{3}{*}{ Pelaku usaha } & $\begin{array}{l}\text { - Peningkatan tingkat } \\
\text { pendidikan untuk } \\
\text { peningkatan mindset } \\
\text { dalam berusaha. }\end{array}$ & $\begin{array}{l}\text { - Mengikuti wajib belajar } 9 \\
\text { tahun atau penyesuaian. } \\
\text { - Mengikuti kegiatan pelatihan } \\
\text { dari Pemda. }\end{array}$ & $\begin{array}{l}\text { - Menjaga hubungan dengan } \\
\text { pihak UPT, sebagai partner } \\
\text { berdiskusi yang baik. } \\
\text { - Hubungan baik dengan } \\
\text { usaha menengah dan usaha } \\
\text { besar. }\end{array}$ \\
\hline & $\begin{array}{l}\text { - Menuju kemandirian } \\
\text { modal. }\end{array}$ & $\begin{array}{l}\text { - Mempelajari dan menyiapkan } \\
\text { berbagai persyaratan yang } \\
\text { diperlukan dalam pengajuan } \\
\text { modal melalui pelatihan } \\
\text { keuangan. Misal: pembuatan } \\
\text { pembukuan keunagan yang } \\
\text { jelas dan rapih. }\end{array}$ & $\begin{array}{l}\text { - Menjaga hubungan dengan } \\
\text { pihak UPT, sebagai partner } \\
\text { berdiskusi yang baik. }\end{array}$ \\
\hline & $\begin{array}{l}\text { - Peningkatan } \\
\text { kemampuan } \\
\text { entrepreneurial } \\
\text { marketing khususnya } \\
\text { pada sub peubah market } \\
\text { intelligence }\end{array}$ & $\begin{array}{l}\text { - Penguatan jaringan informal } \\
\text { dengan semua stakeholder, } \\
\text { yaitu: pemasok, pemerintah, } \\
\text { usaha menengah, dan usaha } \\
\text { besar, serta melakukan } \\
\text { peningkatan kemampuan } \\
\text { pengumpulan informasi } \\
\text { pasar. }\end{array}$ & $\begin{array}{l}\text { - Menjaga hubungan dengan } \\
\text { pihak UPT, sebagai partner } \\
\text { berdiskusi yang baik. } \\
\text { - Hubungan baik dengan } \\
\text { usaha menengah dan usaha } \\
\text { besar. }\end{array}$ \\
\hline \multirow[t]{2}{*}{ Pemerintah } & $\begin{array}{l}\text { - Perbaikan mindset } \\
\text { pelaku usaha. }\end{array}$ & $\begin{array}{l}\text { - Melakukan pelatihan secara } \\
\text { optimal, baik pelatihan: } \\
\text { manajerial, marketing, } \\
\text { produksi dan keuangan, bagi } \\
\text { seluruh karakteristik pelaku } \\
\text { usaha. }\end{array}$ & $\begin{array}{l}\text { - Monev dan pembinaan } \\
\text { intensif pasca pelatihan. }\end{array}$ \\
\hline & $\begin{array}{l}\text { - Peningkatan sub peubah } \\
\text { kebijakan pemerintah } \\
\text { seperti: fasilitasi modal, } \\
\text { kemudahan investasi, } \\
\text { fasilitasi pelatihan, dan } \\
\text { pengendalian } \\
\text { persaingan. }\end{array}$ & $\begin{array}{l}\text { - Bekerja sama dengan pihak } \\
\text { Bank untuk memberikan } \\
\text { persyaratan yang lebih lunak } \\
\text { terkait pembiayaan usaha } \\
\text { alas kaki. } \\
\text { - Bekerja sama dengan pihak } \\
\text { swasta terkait CSR untuk } \\
\text { usaha alas kaki. } \\
\text { - Sosialisasi fungsi kerja dan } \\
\text { keberadaan UPT sebagai } \\
\text { workshop, yang juga melayani } \\
\text { dalam hal permesinan. } \\
\text { - Penyediaan pasar yang pasti. } \\
\text { Misalnya: dengan } \\
\text { menampung hasil-hasil } \\
\text { produksi untuk dipromosikan } \\
\text { pada kalangan internal dan } \\
\text { eksternal Pemda. } \\
\text { - Melakukan pelatihan secara } \\
\text { optimal, baik pelatihan: } \\
\text { manajerial, marketing, } \\
\text { produksi dan keuangan, bagi } \\
\text { seluruh karakteristik pelaku } \\
\text { usaha. } \\
\text { - Penguatan kelompok usaha } \\
\text { bersama (KUB) pengrajin. }\end{array}$ & $\begin{array}{l}\text { - Rencana Aksi Jangka } \\
\text { Menengah Pengembangan } \\
\text { (RAJMP) alas kaki (2012- } \\
\text { 2016) tentang fasilitasi } \\
\text { akses modal. } \\
\text { - Rencana Aksi Jangka } \\
\text { Menengah Pengembangan } \\
\text { (RAJMP) alas kaki (2017- } \\
\text { 2025) tentang peningkatan } \\
\text { akses pendanaan. } \\
\text { - RAJMP alas kaki (2012- } \\
\text { 2016) tentang bantuan } \\
\text { peralatan sesuai } \\
\text { kebutuhan. } \\
\text { - RAJMP alas kaki (2012- } \\
\text { 2016) mengenai fasilitasi } \\
\text { pemasaran. } \\
\text { - RAJPP alas kaki (2017-2025) } \\
\text { mengenai pembentukan } \\
\text { lembaga promosi dan } \\
\text { fasilitasi promosi. } \\
\text { - Penguatan fungsi Kosebo, } \\
\text { UPT, Disperindag, BPT, dan } \\
\text { UKM dalam hal pemasaran } \\
\text { produk. } \\
\text { - Monev dan pembinaan } \\
\text { intensif pasca pelatihan. } \\
\text { 2016) mengenai } \\
\text { pembinaan KUB pengrajin. }\end{array}$ \\
\hline
\end{tabular}




\section{Kesimpulan}

Karakteristik pelaku usaha alas kaki di Bogor secara umum termasuk pada kelompok dengan tingkat pendidikan yang masih rendah dengan mindset jangka pendek. Meski demikian, mereka memiliki keahlian yang sangat baik dalam memproduksi alas kaki. Disamping itu, IK alas kaki di Bogor termasuk usaha yang telah lama berdiri dengan proses produksi manual, dan merupakan usaha pokok yang menjadi sumber utama pendapatan keluarga. Tingkat pendidikan berperan penting dalam menunjang usaha mereka, baik dalam hal skala usaha dan perolehan omset (Rp). Kepemilikan modal merupakan salah satu faktor yang berkaitan dengan eksistensi dan keberlanjutan usaha kecil alas kaki di Bogor.

Secara umum kemampuan entrepreneurial marketing yang dimiliki pelaku usaha alas kaki di wilayah Bogor termasuk pada kategori cukup tinggi. Sedangkan untuk implementasi kebijakan pemerintah, sebagian besar pelaku usaha masih belum merasakan realisasinya. Meski menghadapi berbagai macam kendala dalam industri alas kaki, mayoritas pelaku usaha alas kaki di wilayah Bogor memiliki kemampuan daya saing yang cukup baik.

Berdasarkan analisis SEM dengan pendekatan PLS, diketahui bahwa peubah laten entrepreneurial marketing berpengaruh positif secara langsung terhadap daya saing industri kecil alas kaki di Bogor. Peubah laten kebijakan pemerintah berpengaruh positif secara langsung pada laten entrepreneurial marketing. Hal ini menunjukkan adanya pengaruh tidak langsung antara kebijakan pemerintah terhadap daya saing melalui entrepreneurial marketing.

\section{Daftar Pustaka}

Bjerke B, and Hutlman CM. 2002. Entrepreurial Marketing: The Growth of small firms in the new economic era, Gloucestershire, Edward Elgar.

Crosier K. 2006. What Exactly is Marketing? Quarterly Review of Marketing. 1(2):21-50.

Ghozali I. 2008. Structural Equation Modelling Metode Alternatif dengan Partial Least Square. Edisi 2. Semarang (ID): Badan Penerbit Universitas Diponegoro.

Hills GE. 2008. Marketing and Entrepreneurship, Research Ideas and Opportunities. Journal SMEs of Research Marketing and Entrepreneurship. 2(4).

Hadiyati E. 2009. Kajian Pendekatan Pemasaran Kewirausahaan dan Kinerja Penjualan Usaha Kecil. Jurnal Manajemen dan Kewirausahaan. 11(2):183-192.

Ionita D. 2012. Entrepreneurial Marketing: A New Approach for Challenging Times. Journal of Management and Marketing Challenges for the Knowledge Society. 7(1): 131-150.

Kohli AK, and Jaworski BJ. 2005. Market Orientation: The construct, Research Preposition and Managerial Implication. Jurnal of Marketing. 54(2): 1-18.

Kraus S, Fink M, RossI D, Jensen SH. 2007. Marketing in small and medium sized enterprises. International Business Journal. 7(3). ISSN: 1546-2609.

Kusumawati R, Siregar H, Budiharsono S, Ridwan WA. 2010. Analisis Kebijakan Pengembangan Ekonomi Lokal Industri Alas Kaki yang Berkelanjutan di Kabupaten Bogor. Forum Pascasarjana. 33(3): 165-176. 
Malhotra NK. 2005. Riset Pemasaran Pendekatan Terapan. Jilid 1. Jakarta (ID): PT. Indeks.

Rofiaty. 2010. Pengaruh Turbulensi Lingkungan, Knowledge Sharing Behaviour, dan Strategi Inovasi terhadap Kinerja Usaha Kecil Menengah Kerajinan Sepatu Kulit di Mojokerto. Jurnal Ekonomika-Bisnis. 2(2): 385-394.

Singarimbun M, dan S. Effendi. 1995. Metode Penelitian Survai. Jakarta (ID): Pustaka LP3ES.

Stokes D. 2000. Putting Entrepreneurship Into Marketing. Journal of Research in Marketing \& Entrepreneurship. 2(1).

Tambunan T. 2010. Ukuran Daya Saing Koperasi dan IKM. Background Study RPJM Nasional Tahun 2010-2014 Bidang Pemberdayaan Koperasi dan IKM, Bappenas. Jakarta (ID): Pusat Studi Industri dan IKM, Universitas Trisakti, Kadin Indonesia.

Utami HN. 2007. Keberdayaan, Kemajuan dan Keberlanjutan Usaha Pengrajin : Kasus Kabupaten Sidoarjo dan Kabupaten Magetan Provinsi Jawa Timur [disertasi]. Bogor (ID): Institut Pertanian Bogor.

Winarno B. 2002. Kebijakan dan Proses Kebijakan Publik. Yogyakarta (ID): Media Pressindo. 